Original Article

\title{
Applications of CTAB modified magnetic nanoparticles for removal of chromium (VI) from contaminated water
}

\author{
Souad A. Elfeky ${ }^{\mathrm{a}, *}$, Shymaa Ebrahim Mahmoud ${ }^{\mathrm{b}}$, Ahmed Fahmy Youssef ${ }^{\mathrm{c}}$ \\ ${ }^{a}$ National Institute of Laser Enhanced Science (NILES), Cairo University, Giza 12613, Egypt \\ ${ }^{\mathrm{b}}$ Cairo University Centre for Environmental Hazards Mitigation (CEHM), Cairo University, Giza 12613, Egypt \\ ${ }^{\text {c } C h e m i s t r y ~ D e p a r t m e n t, ~ F a c u l t y ~ o f ~ S c i e n c e, ~ C a i r o ~ U n i v e r s i t y, ~ G i z a ~ 12613, ~ E g y p t ~}$
}

\section{A R T I C L E I N F O}

\section{Article history:}

Received 22 March 2017

Revised 9 June 2017

Accepted 9 June 2017

Available online 10 June 2017

\section{Keywords:}

Magnetic nanoparticles

Composite dosage

TEM

$\mathrm{XRD}$

$\mathrm{pH}$

$\mathrm{Cr}(\mathrm{VI})$

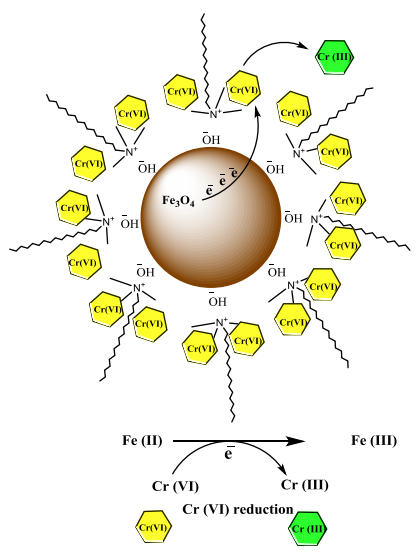

under the CC BY-NC-ND license (http://creativecommons.org/licenses/by-nc-nd/4.0/).

\footnotetext{
Peer review under responsibility of Cairo University.

* Corresponding author.

E-mail address: dr_souad_elfeky@niles.edu.eg (S.A. Elfeky).
}

\begin{abstract}
A B S T R A C T
This study investigated the elimination of $\mathrm{Cr}(\mathrm{VI})$ from aqueous solution utilizing a composite from magnetic nanoparticles $\left(\mathrm{Fe}_{3} \mathrm{O}_{4}\right)$ capped with cetyltrimethylammonium bromide (CTAB). The structure of the prepared composite system was examined by Fourier Transform Infra Red Spectroscopy (FTIR), X-ray Diffractometry (XRD), and Transmission Electron Microscopy (TEM). Separation of the $\mathrm{Fe}_{3} \mathrm{O}_{4} / \mathrm{CTAB}$ composite from the wastewater can be achieved by application of an external magnetic field. Factors affecting the $\mathrm{Cr}(\mathrm{VI})$ expulsion from wastewater such as $\mathrm{pH}$, competing ions, the dosage level of the nanoparticles, and contact time were studied. The results indicated that the maximum efficiency of the present system for removal of $\mathrm{Cr}(\mathrm{VI})(95.77 \%$ ) was in acidic conditions ( $\mathrm{pH} 4$ ), contact time $12 \mathrm{~h}$, and composite dosage of $12 \mathrm{mg} / \mathrm{mL}$. The used $\mathrm{Cr}(\mathrm{VI})$ concentration was $100 \mathrm{mg} / \mathrm{L}$. Considering results, the $\mathrm{Fe}_{3} \mathrm{O}_{4} / \mathrm{CTAB}$ system showed a high capability and selectivity for the treatment of water sullied with $\mathrm{Cr}(\mathrm{VI})$. This can recede the mutagenic and carcinogenic health risk caused by $\mathrm{Cr}(\mathrm{VI})$ water tainting.

(c) 2017 Production and hosting by Elsevier B.V. on behalf of Cairo University. This is an open access article under the CC BY-NC-ND license (http://creativecommons.org/licenses/by-nc-nd/4.0/).
\end{abstract}

\section{Introduction}

Study of water remediation from contaminants such as toxic heavy metals is one of the most important environmental issues. Contaminants can pose serious health and environmental prob- 
lems [1]. The literature survey confirms that chromium has two oxidation states, hexavalent $\mathrm{Cr}(\mathrm{VI})$ and trivalent $\mathrm{Cr}(\mathrm{III})$ [2]. The latter is essential in mammals life and it is concluded that $\mathrm{Cr}(\mathrm{VI})$ is more toxic, mutagenic, carcinogenic and hazardous than $\mathrm{Cr}(\mathrm{III})$ by 500 times. $\mathrm{Cr}(\mathrm{VI})$ can be found as chromate $\left(\mathrm{CrO}_{4}^{2-}\right)$, hydrogen chromate $\left(\mathrm{HCrO}_{4}^{-}\right)$, dichromate $\left(\mathrm{Cr}_{2} \mathrm{O}_{7}^{2-}\right)$, and hydrogen dichromate $\left(\mathrm{HCr}_{2} \mathrm{O}_{7}^{-}\right)$stable oxyanions in wastewater [3]. The highly toxic transition heavy metal $\mathrm{Cr}(\mathrm{VI})$ has a harmful and destroying effect on the human biological system. It is found in wastewater streams from mining, stainless steel production, textile industry, and dyes [4-6].

US Environmental Protection Agency (EPA) indicates that the allowed contamination level for chromium ion in potable water is $0.1 \mathrm{mg} / \mathrm{L}$, while the concentration of the discharge to inland surface water is $0.5 \mathrm{mg} / \mathrm{L}$ [7]. Adsorption is the sufficient technique for $\mathrm{Cr}(\mathrm{VI})$ removal from industrial wastewater [8]. The guideline prescribed by the World Health Organization (WHO) for $\mathrm{Cr}(\mathrm{VI})$ in drinking water is $16 \mathrm{mg} / \mathrm{L}$ [9]. The effluent from industries containing $\mathrm{Cr}(\mathrm{VI})$ is considered by the International Agency for Research on Cancer (IARC) (1982) as a powerful carcinogenic agent that modifies the DNA transcription process causing important chromosomal aberration [10].

Wastewater treatment using the adsorption techniques is more effective than using other techniques as precipitation, coagulation, chemical reduction, and ion exchange [11]. Magnetic nanoparticles are a good candidate for heavy metal adsorption from aqueous solution. Due to the four unpaired electrons in the $3 \mathrm{~d}$ shell, an iron atom has a strong magnetic moment. $\mathrm{Fe}^{2+}$ ions have 4 unpaired electrons in their $3 \mathrm{~d}$ shell and $\mathrm{Fe}^{3+}$ ions have 5 unpaired electrons in their $3 \mathrm{~d}$ shell. Thus, the formed crystals from iron ions of $\mathrm{Fe}^{2+}$ or $\mathrm{Fe}^{3+}$, can be in ferromagnetic or ferrimagnetic states [12]. Magnetite nanoparticles are susceptible to air oxidation and can be easily aggregated in aqueous systems [13]. The stabilization of the iron oxide nanoparticles by adding surfactants as a type of surface modification is desirable. This can change in the surface layer properties to become more different from that in the core of the nanoparticles [14]. The properties of the nanocrystals strongly depend on the dimension of the nanoparticles [15,16].

$\mathrm{Fe}_{3} \mathrm{O}_{4}$ and $\mathrm{Fe}_{2} \mathrm{O}_{3}$ nanoparticles stabilized by Aloe Vera were successfully applied before for the elimination of mercury (70\%) from a wastewater sample [17]. $\mathrm{Fe}_{3} \mathrm{O}_{4}$ /talc nanocomposite was used for the removal of $\mathrm{Cu}(\mathrm{II}), \mathrm{Ni}(\mathrm{II})$, and $\mathrm{Pb}$ (II) ions from aqueous solutions. The results showed $72.15 \%, 50.23 \%$, and $91.35 \%$ removal efficiency for $\mathrm{Cu}(\mathrm{II}), \mathrm{Ni}(\mathrm{II})$, and $\mathrm{Pb}(\mathrm{II})$, respectively [18]. $\mathrm{Fe}_{3} \mathrm{O}_{4}$ magnetic nanoparticles modified with Schiff base ligand were prepared to remove heavy metal ions from aqueous solutions. The maximum adsorption capacities were $97.2,87$, and $81.6 \mathrm{mg} \mathrm{g}^{-1}$ for $\mathrm{Cu}(\mathrm{II})$, $\mathrm{Zn}(\mathrm{II})$, and $\mathrm{Ni}(\mathrm{II})$, respectively [19].

Surfactants are used to lower the surface tension of liquids and have a structure that cannot easily be detected by conventional methods. Cetyltrimethylammonium bromide (CTAB) is a common surfactant used in nanoparticles synthesis. CTAB has a 16-carbon as a long tail and an ammonium head group with three methyl groups attached. Here CTAB can be used for the removal of heavy metals from wastewater [20]. CTAB is a positively charged surfactant, used as a coating agent. CTAB can appear as rod-like micelles with increasing its concentration [21-23]. Jin et al. had succeeded in preparing the $\mathrm{Fe}_{3} \mathrm{O}_{4}$ composite capped with CTAB for arsenate removal from water. $\mathrm{Fe}_{3} \mathrm{O}_{4} / \mathrm{CTAB}$ was prepared by a modified simple co-precipitation process using cheap and environmentally friendly iron salts and the cationic surfactant CTAB [24].

This work aims to develop magnetic nanoparticles (MNPs) coated with CTAB as an efficient composite for the removal of toxic $\mathrm{Cr}(\mathrm{VI})$ from wastewater. It is evident from literature survey that, this is the first time that $\mathrm{Cr}(\mathrm{VI})$ elimination and quantification from wastewater samples based on $\mathrm{Fe}_{3} \mathrm{O}_{4}$ and $\mathrm{Fe}_{3} \mathrm{O}_{4} / \mathrm{CTAB}$ is described.
Schematic representation of $\mathrm{Cr}(\mathrm{VI})$ elimination by $\mathrm{Fe}_{3} \mathrm{O}_{4} / \mathrm{CTAB}$ is sketched in Scheme 1 . The $\mathrm{Fe}_{3} \mathrm{O}_{4} / \mathrm{CTAB}$ has some advantages such as facile synthesis and simple regeneration in alkali solutions. Thus, favoring its reusing or recycling purposes. It also can be easily collected by external magnetic field for the regeneration process. Furthermore, this composite is cheap and effective in the removal of $\mathrm{Cr}(\mathrm{VI})$ from wastewater.

\section{Material and methods}

Reagents

All chemicals that used in this work are analytical grade reagents. Iron (III) chloride $97 \%\left(\mathrm{FeCl}_{3}\right)$, iron (II) chloride tetrahydrate $98 \%\left(\mathrm{FeCl}_{2} \cdot 4 \mathrm{H}_{2} \mathrm{O}\right)$, potassium chromate $\left(\mathrm{K}_{2} \mathrm{CrO}_{4}\right) 99 \%$, Cetyltrimethylammonium bromide (CTAB) 95\% and ammonium solution 25\% were purchased from Sigma-Aldrich (Missouri, USA). Nitrite standard, sulfate standard, and phosphate standard were purchased from Ultratech (California, USA).

\section{Preparation of $\mathrm{Fe}_{3} \mathrm{O}_{4}$ (magnetic) nanoparticles}

Chemical co-precipitation method is a widely applicable method for synthesis of iron oxide nanoparticles. It involves mixing of ferric and ferrous salts in $2: 1\left(\mathrm{Fe}^{3+} / \mathrm{Fe}^{2+}\right)$ ratio in a basic aqueous medium (using 25\% ammonium solution) [25]. Formation of $\mathrm{Fe}_{3} \mathrm{O}_{4}$ nanoparticles can be completed at a pH 8.0-10.0 [26].

The formed nanoparticles were washed with deionized water (DI), collected by applying an external magnetic field and dried under vacuum [27].

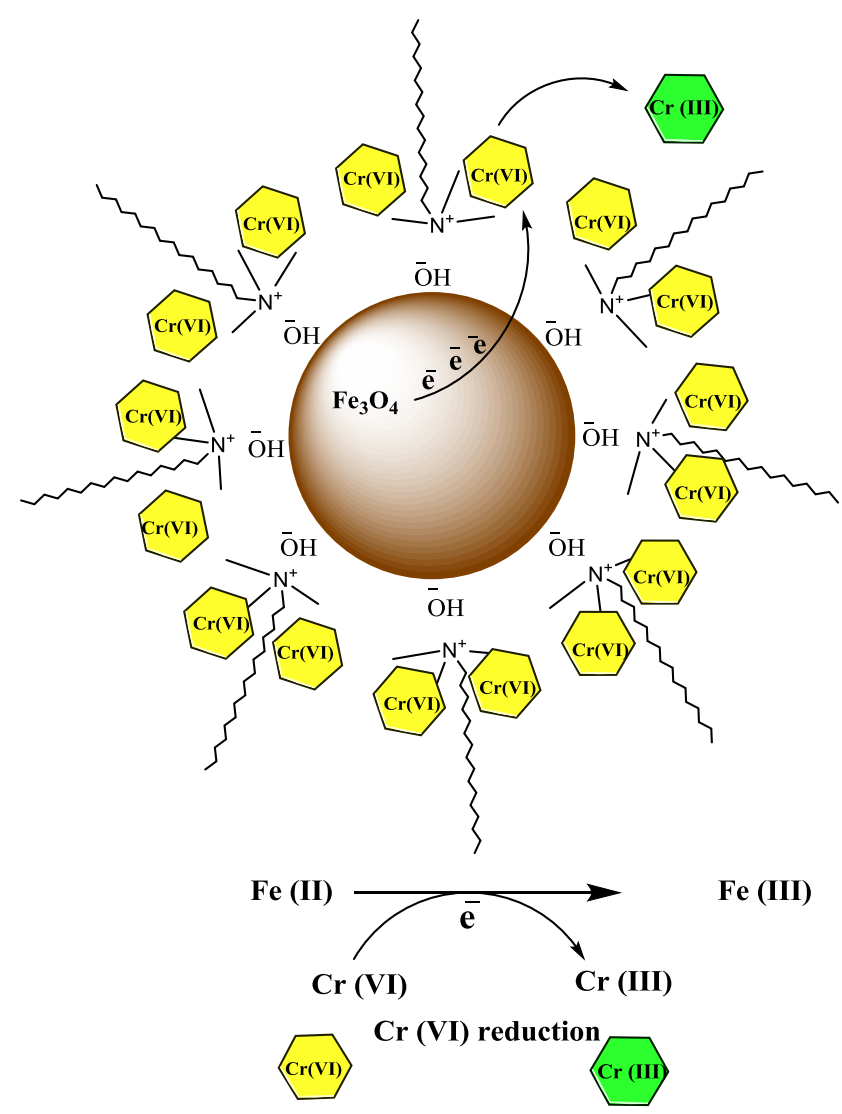

Scheme 1. Adsorption and reduction of $\mathrm{Cr}(\mathrm{VI})$ on the surface of $\mathrm{Fe}_{3} \mathrm{O}_{4} / \mathrm{CTAB}$ nanocomposite. 
Preparation of $\mathrm{Fe}_{3} \mathrm{O}_{4} / \mathrm{CTAB}$ composite

Cationic surfactants have been used for anionic metal removal [28]. Iron (III) chloride ( $0.5 \mathrm{~g}$ ), $0.4 \mathrm{~g}$ of iron (II) chloride tetrahydrate, and $0.4 \mathrm{~g}$ of CTAB was dissolved together in $100 \mathrm{~mL} \mathrm{DI}$, then $25 \%$ ammonium solution was added until the black precipitate was formed. The mixture was stirred for $2 \mathrm{~h}$ and the formed $\mathrm{Fe}_{3} \mathrm{O}_{4} /$ CTAB was collected and washed as mentioned before [11].

\section{Samples processing}

DI was used for all preparations and throughout all experiments. Experiments were carried out at room temperature. Different dosages of $\mathrm{Fe}_{3} \mathrm{O}_{4}$ nanoparticles or $\mathrm{Fe}_{3} \mathrm{O}_{4} / \mathrm{CTAB}(4,8$, and $12 \mathrm{mg} /$ $\mathrm{mL})$ were added in $25 \mathrm{~mL}$ of $\mathrm{DI}$ containing $\mathrm{Cr}(\mathrm{VI})(100 \mathrm{mg} / \mathrm{L})$ solution.

The adsorption capacity of the adsorbents was determined according to Eq. (1) [29].

$Q_{e}=\frac{\left(C_{0}-C_{e}\right) * V}{W}$

where $Q_{e}$ is the equilibrium adsorption capacity of the adsorbent in $\mathrm{mg}$ (metal)/g (adsorbent), $\mathrm{C}_{0}$ is the concentration of metal ions before adsorption in $\mathrm{mg} / \mathrm{L}, \mathrm{C}_{\mathrm{e}}$ is the equilibrium concentration of metal ions in $\mathrm{mg} / \mathrm{L}$ (remained in solution after shaking), $\mathrm{V}$ is the volume of metal ions solution in liter scale, and $\mathrm{W}$ is the weight of the adsorbent in gram scale. The samples were shaken at a rate of $1.17 \mathrm{xg}$ and different contact times $(2,4,6,8,10$, and $12 \mathrm{~h})$ to estimate the best contact time for maximum adsorption. All adsorption experiments were conducted in triplicate and the mean of the three values was expressed as the result. After shaking, the adsorbent was collected by applying an external strong magnet. The concentration of $\mathrm{Cr}(\mathrm{VI})$ in the supernatant as well as in the control samples was determined by flame atomic absorption spectroscopy (FAAS) [30].

\section{Effect of $p H$}

Three $\mathrm{pH}$ values, including acidic, neutral and basic $\mathrm{pH}$ were tested to assess the adsorption capacity of the adsorbent in the different media. The $\mathrm{pH}$ of the samples was adjusted to 4.0, 7.0, and 9.0 using $0.01 \mathrm{~N} \mathrm{NaOH}$ or $0.01 \mathrm{~N} \mathrm{HCl}$. The percentage of removal was calculated from the Eq. (2)

$\%$ Removal $=\left(\frac{\mathrm{C}_{0}-\mathrm{C}_{\mathrm{f}}}{\mathrm{C}_{0}}\right) \times 100$

where $C_{o}$ and $C_{f}$ are the initial and final concentration of heavy metals in the solution, respectively [31]. Additionally, the association between the initial concentration of $\mathrm{Cr}(\mathrm{VI})$ and the adsorption capacity was explored. $8 \mathrm{mg} / \mathrm{mL}$ of $\mathrm{Fe}_{3} \mathrm{O}_{4} / \mathrm{CTAB}$ nanoparticles was added into each flask containing $25 \mathrm{~mL}$ of $\mathrm{Cr}(\mathrm{VI})$ ion solutions with various initial metal ion concentrations (from $10 \mathrm{mg} / \mathrm{L}$ to $200 \mathrm{mg} / \mathrm{L}$ ). All the flasks were shaken at $1.17 \mathrm{xg}$ for $80 \mathrm{~min}$. The adsorbed amount of metal ions onto the $\mathrm{Fe}_{3} \mathrm{O}_{4} / \mathrm{CTAB}$ was calculated according to Eqs. (1) and (2).

\section{Effect of interfering ions}

A series of different concentrations $(1,10,15$ and $20 \mathrm{mg} / \mathrm{L})$ of interfering anions (nitrite, sulfate, and phosphate) was prepared. Each anion was applied separately in a binary system to investigate its interference with the $\mathrm{Cr}(\mathrm{VI})(100 \mathrm{mg} / \mathrm{L})$ adsorption by $\mathrm{Fe}_{3} \mathrm{O}_{4} /$ CTAB composite at $\mathrm{pH} 4$ and $12 \mathrm{~h}$ contact time.

\section{Field sample}

The real field samples were collected from (Ternaries area, Fom El-Khaleg, Cairo Governorate-Egypt). The real field experiment was performed using $12 \mathrm{mg} / \mathrm{mL} \mathrm{Fe}_{3} \mathrm{O}_{4} / \mathrm{CTAB}$ composite and $25 \mathrm{~mL}$ wastewater sample volume. The contact time was $12 \mathrm{~h}$ at $\mathrm{pH} 4$ and shaking rate $1.17 \mathrm{xg}$.

\section{Instruments}

Atomic absorption spectroscopy of $\mathrm{Cr}(\mathrm{VI})$ was measured using a Perkin-Elmer flame atomic absorption spectrometer model 2380 (Perkin-Elmer, Norwalk, Connecticut, USA). The hollow cathode lamp used as a radiation source was operated at a wavelength of $425.4 \mathrm{~nm}$ and the slit width was adjusted to $0.2 \mathrm{~nm}$. The flow of acetylene and air was 4.5 and $15.0 \mathrm{~L} / \mathrm{min}$, respectively. The infrared spectra (4000.6-399.1 $\mathrm{cm}^{-1}$ ) were recorded on a Fourier Transform Infra Red spectrometer JASCO FT/IR-4100 (Jasco, Tokyo, Japan). X-ray diffraction (XRD) pattern was performed using a PANalytical's X'Pert PRO diffractometer (PANalytical, Almelo, Netherlands) with $\mathrm{Cu} \mathrm{K} \alpha$ radiation. The morphology of the $\mathrm{Fe}_{3} \mathrm{O}_{4}$ nanoparticles was observed by the transmission electron microscope (FEI Tecnai G2 20, $200 \mathrm{kV}$ TEM, Oregon, USA). JENWAY 3010 digital $\mathrm{pH} / \mathrm{mV}$ meter (JENWAY, Staffordshire, UK) was used for $\mathrm{pH}$ measurement. Millipore Elix S (Automatic Sanitization Module, Millipore, Massachusetts. USA) was used for the preparation of deionized water.

\section{Results}

Characterization of the prepared magnetic nanoparticles

\section{$X R D$}

The crystal structure and phase purity of the prepared iron oxide nanoparticles were identified by measuring the XRD pattern as shown in Fig. 1.

All the peaks of XRD pattern were analyzed and indexed comparing with magnetite standards. The lattice constants are equal ( $a=b=c=8.3778 \AA$ ) confirming the formation of a cubic structure. The diffraction peaks at $30,35.4,43,53.4,56.9$, and $62.5^{\circ}$ are indexed to planes (220), (311), (400), (422), (511) and (440) of the cubic unit cell. The average $\mathrm{Fe}_{3} \mathrm{O}_{4}$ crystal size estimated from the plane (311) at $2 \theta-35.5^{\circ}$ using the Scherrer formula (Eq. (3)) is $16.25 \mathrm{~nm}$ [32].

$\mathrm{d}=\mathrm{K} \lambda / \beta \cos \theta$

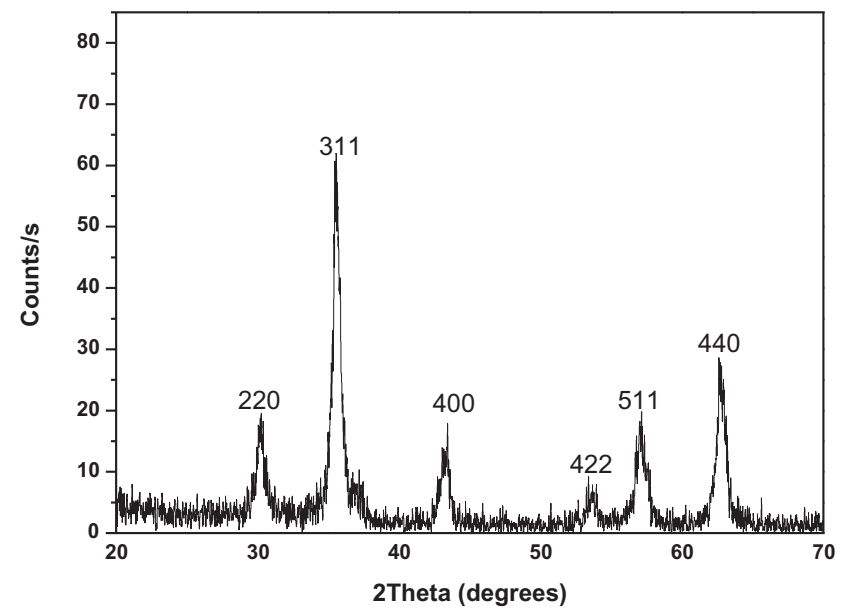

Fig. 1. XRD pattern for $\mathrm{Fe}_{3} \mathrm{O}_{4}$ nanoparticles. 
where $\mathrm{d}$ is the crystal size, $\mathrm{K}$ is the Scherrer constant $(0.89), \lambda$ is the wavelength of the X-ray radiation $(0.15418 \mathrm{~nm}$ for $\mathrm{Cu} \mathrm{K \alpha})$, and $\beta$ is the full width at half maximum of a diffraction peak measured at $2 \theta$.

\section{FTIR}

The IR spectrum of CTAB (Fig. 2a) consists of a band at $3420 \mathrm{~cm}^{-1}$ that could be assigned to the vibrations of the ammonium moiety in CTAB. Peaks at 2918 and $2848 \mathrm{~cm}^{-1}$ are attributed to two different $\mathrm{CH}$ bands vibration of the $-\mathrm{CH}_{2}$ group in $\mathrm{CTAB}$. The bands at 1630 and $1467 \mathrm{~cm}^{-1}$ belong to asymmetric and symmetric stretching vibration of $\mathrm{N}^{+}-\mathrm{CH}_{3}$, while the band at $960 \mathrm{~cm}^{-1}$ corresponds to the out-of-plane $-\mathrm{CH}$ vibration of $\mathrm{CH}_{3}$ [33]. The band at $720 \mathrm{~cm}^{-1}$ could be assigned to $\mathrm{Br}^{-}$. The FTIR spectrum of $\mathrm{Fe}_{3} \mathrm{O}_{4} /$ CTAB nanoparticles (Fig. 2b) displays a peak at $566 \mathrm{~cm}^{-1}$ that represents $\mathrm{Fe}-\mathrm{O}$ of $\mathrm{Fe}_{3} \mathrm{O}_{4}$. The broadband at $3430 \mathrm{~cm}^{-1}$ might be assigned to the electrostatic interaction between $\mathrm{Fe}_{3} \mathrm{O}_{4}$ surface hydroxyl groups and the ammonium moiety in $\operatorname{CTAB}\left(\mathrm{OH}^{-} \ldots \mathrm{N}^{+}\right)$.

\section{TEM}

The TEM image in Fig. 3a showed particles with spherical-like shapes and size range from 10 to $20 \mathrm{~nm}$. There is a good correspondence between $\mathrm{Fe}_{3} \mathrm{O}_{4}$ size shown in the TEM and that calculated from XRD spectrum by Scherrer formula.

The HRTEM image in Fig. 3b shows $\mathrm{Fe}_{3} \mathrm{O}_{4}$ crystal with a wellaligned and single crystalline structure (the d spacing is $0.22 \mathrm{~nm}$ ).

\section{Factors affecting the adsorption process}

\section{Effect of $p H$}

The $\mathrm{pH}$ of the sample influences the adsorption progress by protonation and deprotonation of adsorbent surface functional groups. The effect of different $\mathrm{pH}$ values $(4,7$, and 9$)$ on the adsorption of $\mathrm{Cr}(\mathrm{VI})$ by nanoparticles ( 4 and $12 \mathrm{mg} / \mathrm{mL}$ ) for $8 \mathrm{~h}$ contact time was investigated.

Table 1 showed that the maximum adsorption of $\mathrm{Cr}(\mathrm{VI})$ was observed at pH 4 for both adsorbents after $8 \mathrm{~h}$ contact time.

From Table 1 it is obvious that the composite of $\mathrm{Fe}_{3} \mathrm{O}_{4} / \mathrm{CTAB}$ adsorption efficiency is higher than $\mathrm{Fe}_{3} \mathrm{O}_{4}$ in acidic $\mathrm{pH}$ 4. For example, the same dose $(12 \mathrm{mg} / \mathrm{mL})$ results in $72.47 \% \mathrm{Cr}(\mathrm{VI})$ removal when applying $\mathrm{Fe}_{3} \mathrm{O}_{4}$ nanoparticles whereas it removes $94.19 \%$ after using $\mathrm{Fe}_{3} \mathrm{O}_{4} / \mathrm{CTAB}$.

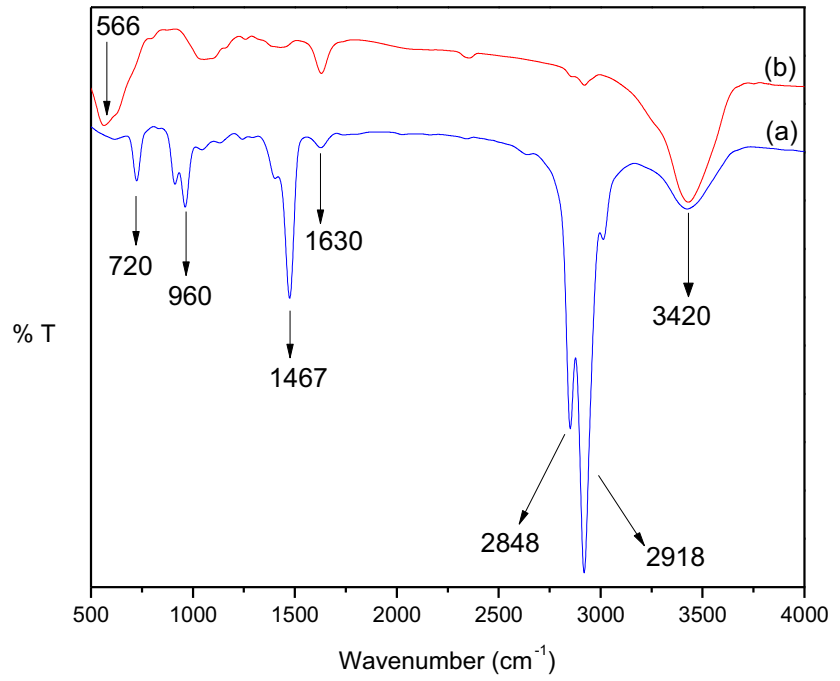

Fig. 2. FTIR of CTAB (a) and $\mathrm{Fe}_{3} \mathrm{O}_{4} / \mathrm{CTAB}$ nanocomposite (b)

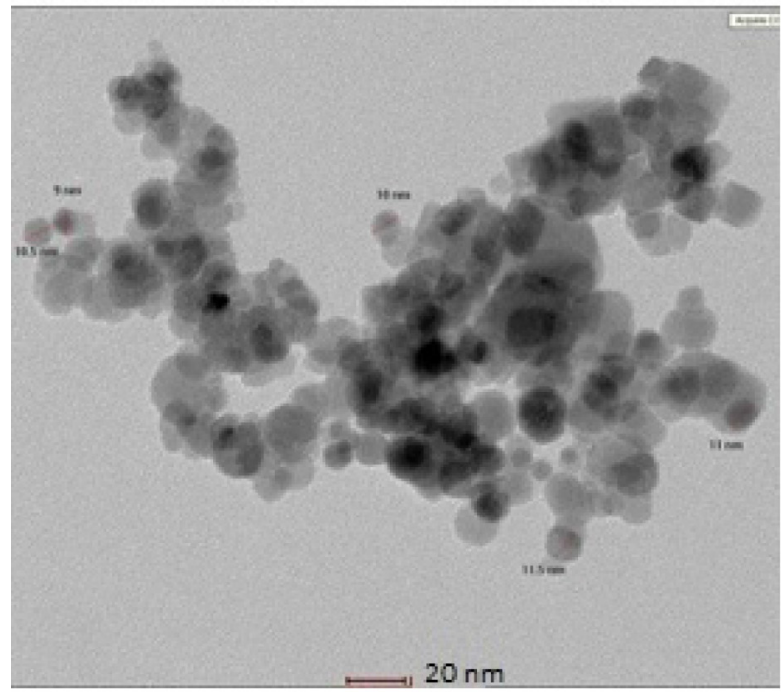

(a)

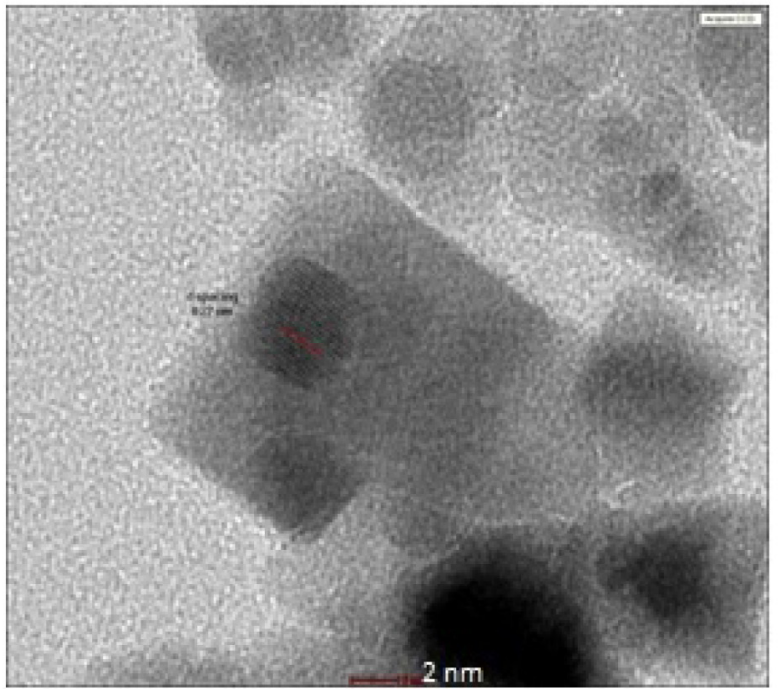

(b)

Fig. 3. TEM (a) and HRTEM (b) images of $\mathrm{Fe}_{3} \mathrm{O}_{4}$ nanoparticles

Table 1

The effect of different $\mathrm{pH}$ values on adsorption of $\mathrm{Cr}(\mathrm{VI})$ by different concentrations from $\mathrm{Fe}_{3} \mathrm{O}_{4}$ nanoparticles or $\mathrm{Fe}_{3} \mathrm{O}_{4} / \mathrm{CTAB}$ nanocomposite after $8 \mathrm{~h}$ contact time.

\begin{tabular}{lll}
\hline $\mathrm{pH}$ & $\mathrm{Fe}_{3} \mathrm{O}_{4}$ & $\mathrm{Fe}_{3} \mathrm{O}_{4} / \mathrm{CTAB}$ \\
\hline & Removal \% & \\
\hline & $4 \mathrm{mg} / \mathrm{mL}$ & \\
4.00 & 25.631 & 27.399 \\
7.00 & 24.621 & 22.096 \\
9.00 & 19.571 & 13.510 \\
& $12 \mathrm{mg} / \mathrm{mL}$ & \\
4.00 & 72.475 & 94.192 \\
7.00 & 40.909 & 44.444 \\
9.00 & 33.586 & 27.778 \\
\hline
\end{tabular}

\section{Effect of nanocomposite dosage}

As evident from studying the effect of $\mathrm{pH}$, removal of $\mathrm{Cr}(\mathrm{VI})$ was more proficient in $\mathrm{pH} 4$ for both adsorbents. Therefore, the effect of nanocomposite dosage will be investigated at this $\mathrm{pH}$ value. Different dosages from both adsorbents $(4,8$, and $12 \mathrm{mg} / \mathrm{mL}$ ) were applied for the removal of $\mathrm{Cr}(\mathrm{VI})$ ions $(100 \mathrm{mg} / \mathrm{L})$ at room temperature $\left(25.0^{\circ} \mathrm{C} \pm 1.0^{\circ} \mathrm{C}\right)$ and at different contact times. From Fig. $4 \mathrm{a}$ and $\mathrm{b}$ it was noted that the removal of the $\mathrm{Cr}(\mathrm{VI})$ ions increases as the concentration of both adsorbents increases. The 

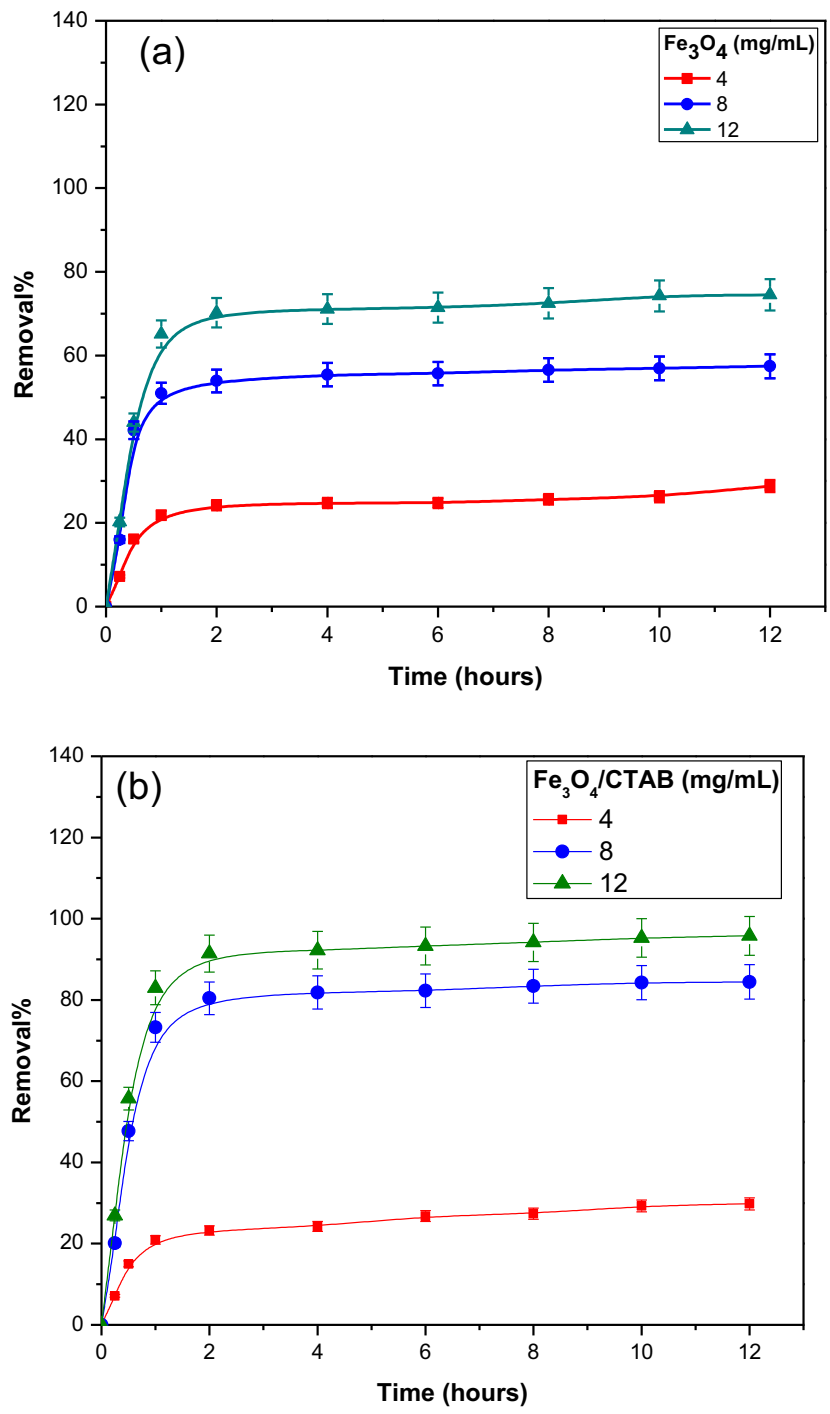

Fig. 4. Removal\% of $\mathrm{Cr}(\mathrm{VI})$ using different dosages from $\mathrm{Fe}_{3} \mathrm{O}_{4}$ nanoparticles (a) and $\mathrm{Fe}_{3} \mathrm{O}_{4} / \mathrm{CTAB}$ nanocomposite (b) at $\mathrm{pH} 4$

optimum dosage $\left(12 \mathrm{mg} / \mathrm{mL}\right.$ ) of the composite $\mathrm{Fe}_{3} \mathrm{O}_{4} / \mathrm{CTAB}$ could stamp out $95.77 \%$ from $\mathrm{Cr}(\mathrm{VI})$ while an equivalent amount from $\mathrm{Fe}_{3} \mathrm{O}_{4}$ adsorbs $74.49 \%$ of $\mathrm{Cr}(\mathrm{VI})$ after $12 \mathrm{~h}$ contact time. The intermediate amount $(8 \mathrm{mg} / \mathrm{mL})$ from both $\mathrm{Fe}_{3} \mathrm{O}_{4} / \mathrm{CTAB}$ and $\mathrm{Fe}_{3} \mathrm{O}_{4}$ nanoparticles wipes out $84.4 \%$ and $57.4 \% \mathrm{Cr}(\mathrm{VI})$, respectively.

The maximum adsorption capacity was achieved for both adsorbents at $8 \mathrm{mg} / \mathrm{mL}$ dosage level using $100 \mathrm{mg} / \mathrm{L} \mathrm{Cr}(\mathrm{VI})$ concentration. It was $6.74 \mathrm{mg} / \mathrm{g}$ (Fig. 5-a) and $10.05 \mathrm{mg} / \mathrm{g}$ (Fig. $5 \mathrm{~b}$ ) for $\mathrm{Fe}_{3} \mathrm{O}_{4}$ and $\mathrm{Fe}_{3} \mathrm{O}_{4} / \mathrm{CTAB}$, respectively.

From the adsorption capacity values, it appears that $\mathrm{Fe}_{3} \mathrm{O}_{4} / \mathrm{CTAB}$ has a better adsorption than bare $\mathrm{Fe}_{3} \mathrm{O}_{4}$.

\section{Adsorption kinetic study}

The metal adsorption mechanism can be explored by applying the pseudo-first-order and pseudo-second-order kinetic models. The pseudo-first-order kinetic model equation assumes that the binding is originated from a physical adsorption as follows [34].

$\log \left(q_{e}-q_{t}\right)=\log q_{e} \frac{K 1}{2.303} t$

where $\mathrm{q}_{\mathrm{e}}$ and $\mathrm{q}_{\mathrm{t}}$ are the amount of heavy metal ions adsorbed on the adsorbent in $\mathrm{mg}$ (metal)/g (adsorbent) at equilibrium and at time $\mathrm{t}$, respectively. $K_{1}$ is the constant of first-order kinetics in $\min ^{-1}$.
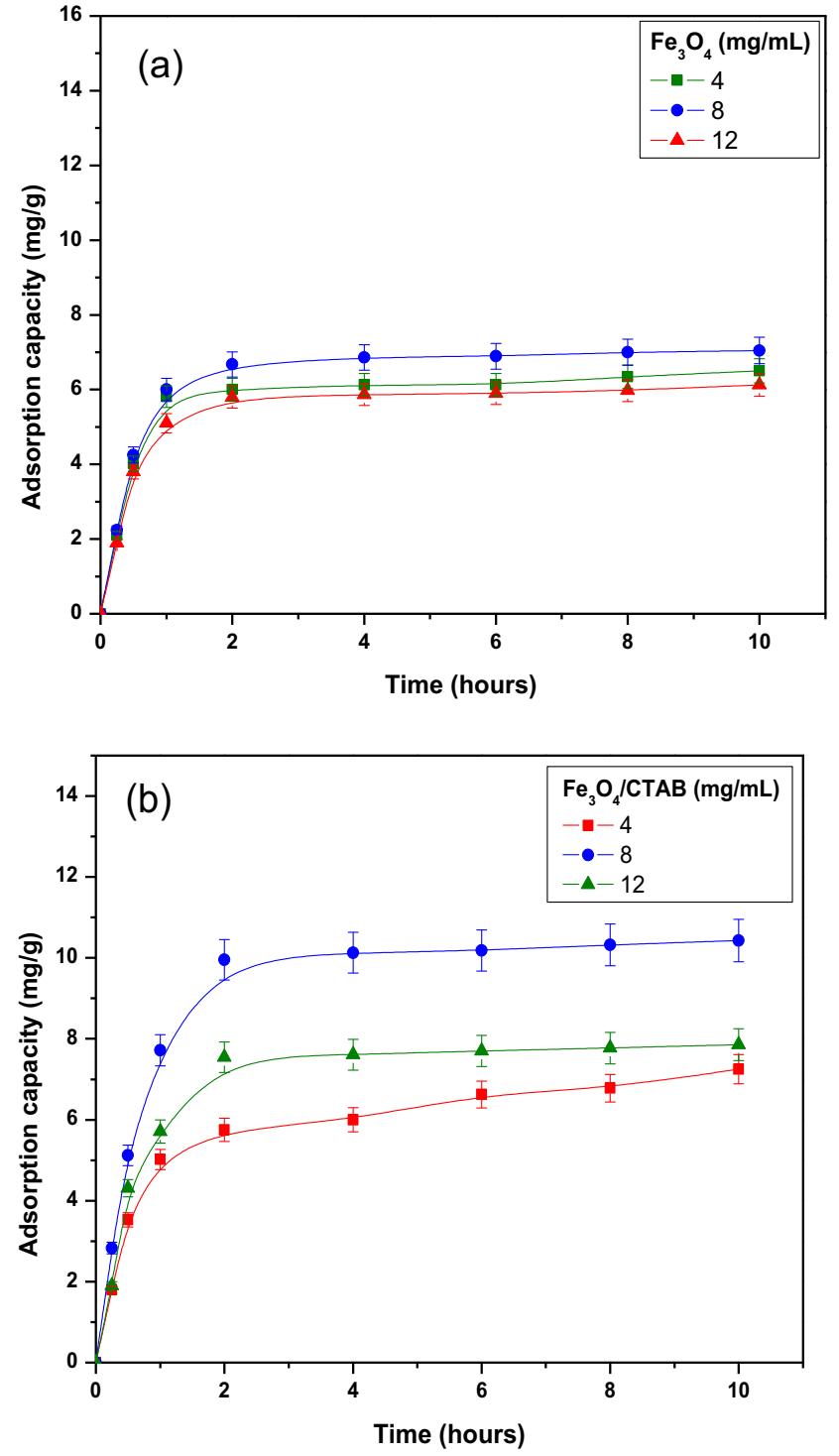

Fig. 5. Time dependence for the adsorption capacity of $\mathrm{Cr}(\mathrm{VI})$ using different dosages from $\mathrm{Fe}_{3} \mathrm{O}_{4}$ nanoparticles (a) and $\mathrm{Fe}_{3} \mathrm{O}_{4} / \mathrm{CTAB}$ nanocomposite (b) at $\mathrm{pH} 4$ and $10 \mathrm{~h}$ contact time.

While the pseudo-second-order kinetic model is based on chemical adsorption (chemisorption) as follows [29].

$\frac{t}{q_{t}}=\frac{1}{k_{2} q_{e}^{2}}+\frac{t}{q_{e}}$

where $\mathrm{q}_{\mathrm{e}}$ and $\mathrm{q}_{\mathrm{t}}$ are the amount of heavy metal ions adsorbed by the adsorbent in $\mathrm{mg}$ (metal)/g (adsorbent) at equilibrium and at time $\mathrm{t}$, respectively. $K_{2}$ is the rate constant of second-order kinetics in $g /$ (mg min).

The values of $\mathrm{K}_{1}$ and $\mathrm{K}_{2}$ for $\mathrm{Fe}_{3} \mathrm{O}_{4} / \mathrm{CTAB}$ were experimentally determined from Eqs. (4) and (5), respectively. The fitting curves obtained from the linear plots of $\log \left(\mathrm{q}_{\mathrm{e}}-\mathrm{q}_{\mathrm{t}}\right)$ versus time and $\mathrm{t} / \mathrm{q}_{\mathrm{t}}$ versus time are plotted in Fig. $6 \mathrm{a}$ and b respectively. From Fig. 6 it appears that the second order model seems to be more favorable for the $\mathrm{Cr}(\mathrm{VI})$ sorption process indicating its chemical adsorption by $\mathrm{Fe}_{3} \mathrm{O}_{4} / \mathrm{CTAB}$ nanocomposite.

The obtained $\mathrm{K}_{1}$ and $\mathrm{K}_{2}$ values for $\mathrm{Fe}_{3} \mathrm{O}_{4}$ and $\mathrm{Fe}_{3} \mathrm{O}_{4} / \mathrm{CTAB}$ nanocomposite plus other parameters obtained from the linear form of pseudo-first-order and pseudo-second-order are listed in the Table 2 . 

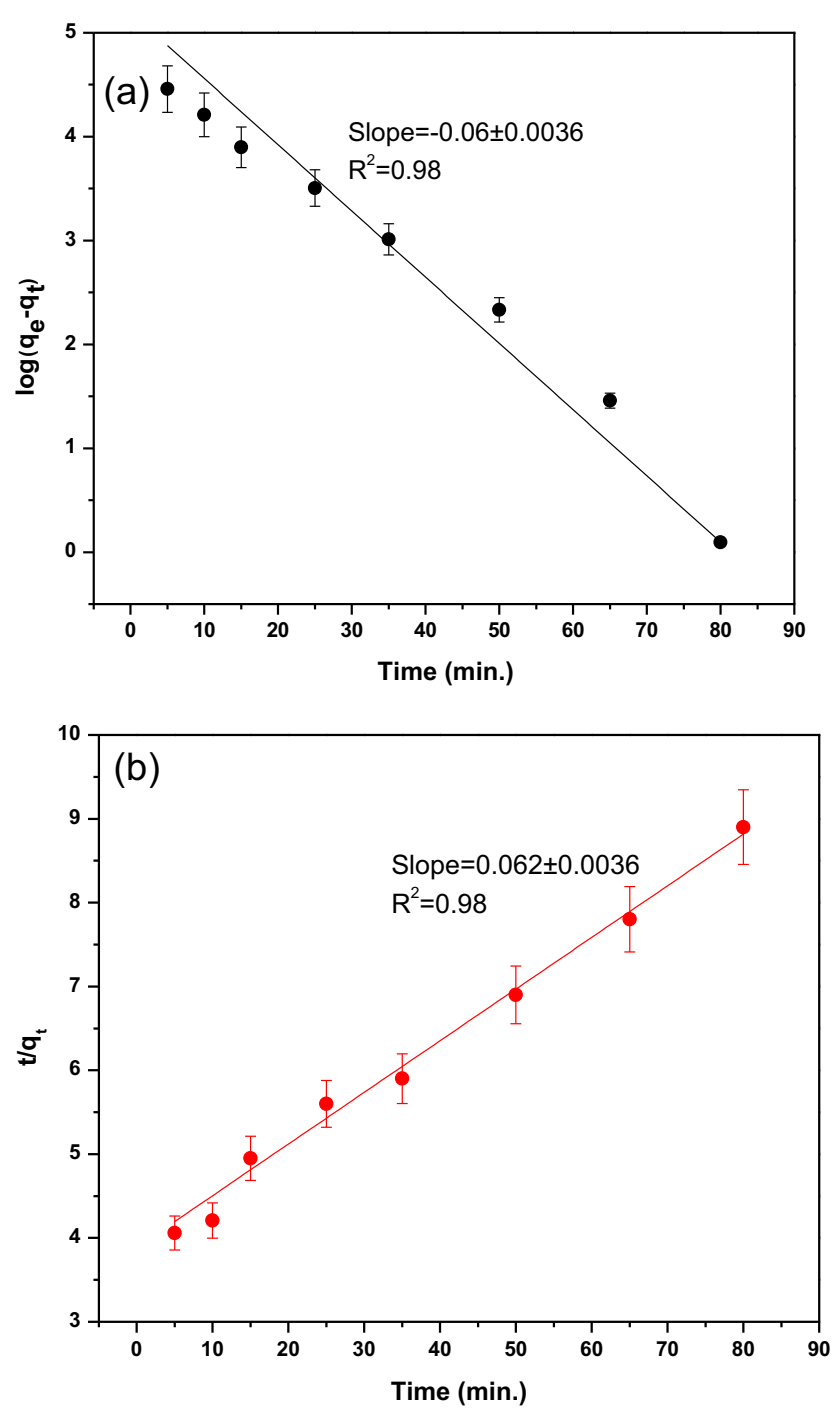

Fig. 6. Plot of pseudo first order (a) and pseudo second order (b) models for the sorption of $\mathrm{Cr}(\mathrm{VI})$ from contaminated sample using $\mathrm{Fe}_{3} \mathrm{O}_{4} / \mathrm{CTAB}$ nanocomposite.

Table 2

Parameters of kinetic models for the sorption of $\mathrm{Cr}(\mathrm{VI})$ by $\mathrm{Fe}_{3} \mathrm{O}_{4}$ and $\mathrm{Fe}_{3} \mathrm{O}_{4} / \mathrm{CTAB}$ nanocomposite.

\begin{tabular}{lll}
\hline Parameters & $\mathrm{Fe}_{3} \mathrm{O}_{4}$ & $\mathrm{Fe}_{3} \mathrm{O}_{4} / \mathrm{CTAB}$ \\
\hline $\mathrm{Q}_{\mathrm{e}}(\mathrm{mg} / \mathrm{g})$ & 6.74 & 10.05 \\
$\mathrm{SE}$ & 0.006 & 0.004 \\
Pseudo first order model & & \\
$\mathrm{K}_{1}\left(\mathrm{~min}^{-1}\right)$ & 0.012 & 0.064 \\
$\mathrm{R}^{2}$ (correlation coefficient) & 0.95 & 0.98 \\
$\mathrm{SE}$ & 0.0009 & 0.003 \\
Pseudo second order model & & \\
$\mathrm{K}_{2}\left(\mathrm{~g} \mathrm{mg}^{-1} \mathrm{~min}^{-1}\right)$ & 0.002 & 0.001 \\
$\mathrm{R}^{2}$ (correlation coefficient) & 0.96 & 0.99 \\
$\mathrm{SE}$ & 0.007 & 0.003 \\
\hline
\end{tabular}

\section{Equilibrium modeling}

The common isotherm models (Langmuir and Freundlich), were used to describe the adsorption of $\mathrm{Cr}(\mathrm{VI})$ ion on the $\mathrm{Fe}_{3} \mathrm{O}_{4} / \mathrm{CTAB}$ nanocomposite. Langmuir model supposed that all the adsorption sites of the adsorbent have the same binding energy and every site joints to only one adsorbate [35].

The linearized Langmuir isotherm is given by Eq. (6):
$\frac{C_{e}}{q_{e}}=\frac{1}{q_{m} b}+\frac{C_{e}}{q_{m}}$

where $\mathrm{q}_{\mathrm{e}}$ is the equilibrium adsorption capacity of the adsorbent in $\mathrm{mg}$ (metal)/g (adsorbent), $\mathrm{C}_{\mathrm{e}}$ is the equilibrium concentration of metal ions in $\mathrm{mg} / \mathrm{L}, \mathrm{q}_{\mathrm{m}}$ is the maximum amount of metal adsorbed in $\mathrm{mg}$ (metal)/g (adsorbent), and $\mathrm{b}$ is the constant that belongs to the bonding energy of adsorption in $\mathrm{L} / \mathrm{mg}$.

On the other hand, Freundlich isotherm assumes heterogeneity of binding energies of adsorption sites [35]. The linearized Freundlich isotherm is given by Eq. (7):

$\log q_{e}=\log K_{f}+\frac{1}{n} \log C_{e}$

where $\mathrm{q}_{\mathrm{e}}$ is the equilibrium adsorption capacity of the adsorbent in $\mathrm{mg}$ (metal)/g (adsorbent), $\mathrm{C}_{\mathrm{e}}$ is the equilibrium concentration of heavy metal ions in $\mathrm{mg} / \mathrm{L}, \mathrm{K}_{\mathrm{f}}$ is the constant refers to the adsorption capacity of the adsorbent in $\mathrm{mg} / \mathrm{L}$, and $\mathrm{n}$ is the constant linked to the adsorption intensity.

Usually, for the valuation of preeminent fit, values of correlation coefficients $\left(R^{2}\right)$ of linear plots of the two models are compared. The correlation coefficient is higher $\left(R^{2}=0.99\right)$ in the case of applying a Langmuir model (Fig. 7a) than Freundlich model $\left(R^{2}=0.95\right)$ as
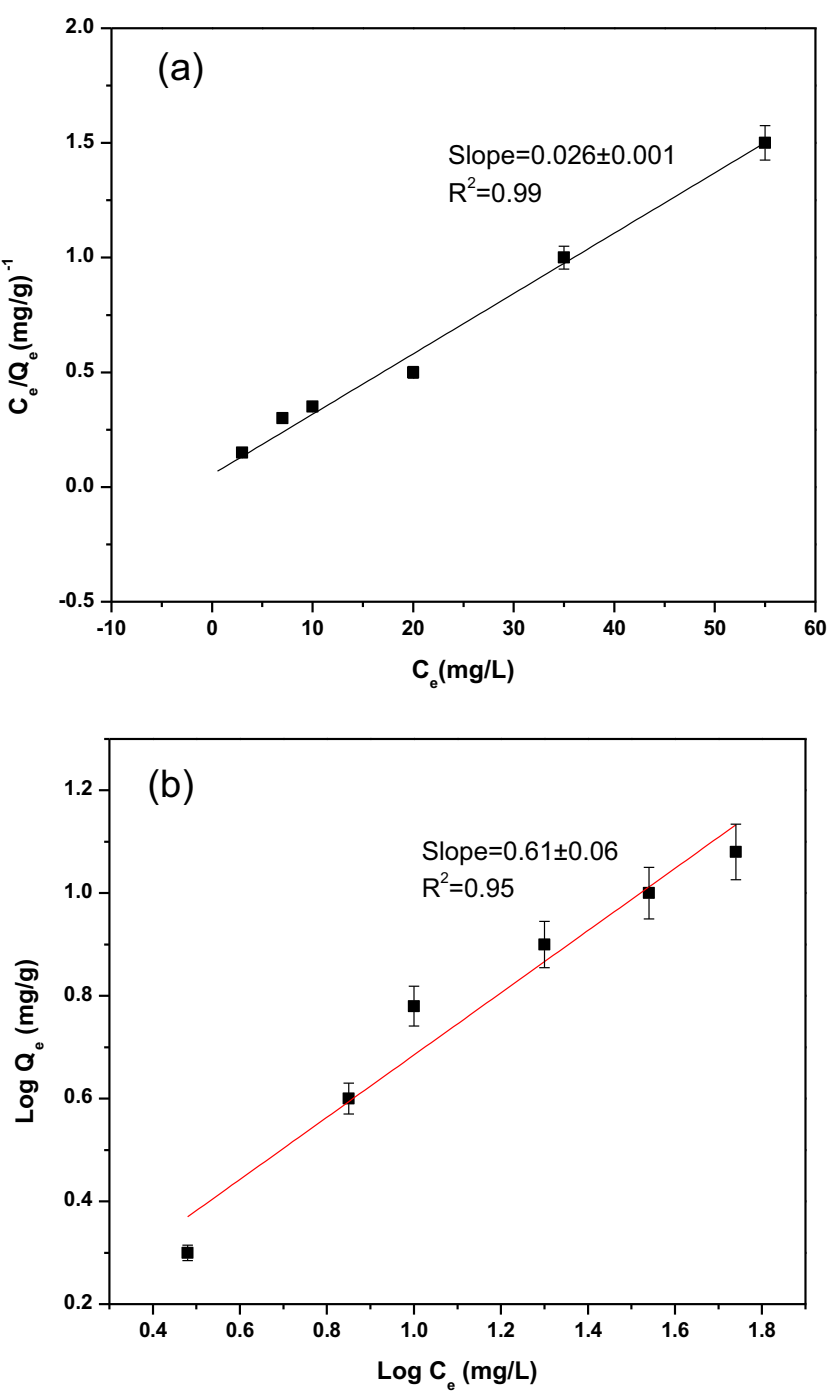

Fig. 7. Adsorption isotherm of $\mathrm{Cr}(\mathrm{VI})$ ion onto the $\mathrm{Fe}_{3} \mathrm{O}_{4} / \mathrm{CTAB}$ nanocomposite plotted by (a) Langmuir model and (b) Freundlich model. 
shown in Fig. 7 (b). The correlation coefficients and other parameters for both models are presented in Table 3.

\section{Effect of interfering ions}

Some anions can compete with $\mathrm{Cr}(\mathrm{VI})$ at the adsorption process by the nanoparticles. As $\mathrm{Fe}_{3} \mathrm{O}_{4} / \mathrm{CTAB}$ nanocomposite gives a better adsorption results, it was applied to investigate the effect of competitive anions at a $\mathrm{pH} 4$ and at a contact time $12 \mathrm{~h}$. As can be seen from Fig. 8 the $\mathrm{Cr}(\mathrm{VI})$ ions abolition percentage was 94.89, 93.56, and $90.68 \%$ in the existence of $\mathrm{SO}_{4}^{2-}, \mathrm{NO}_{2}^{-}$or $\mathrm{PO}_{4}^{3-}(20 \mathrm{mg} / \mathrm{mL})$, respectively. These values are very close to the obtained results without competitive ions under the same conditions (95.77\%).

\section{Wastewater field sample test}

Real samples (three replicates) were collected from Ternaries area, Fom El-Khaleg, Cairo Governorate-Egypt. The test was performed to investigate the nanocomposite efficiency in the field applications. The $\mathrm{Fe}_{3} \mathrm{O}_{4} / \mathrm{CTAB}$ composite was chosen for field application at the optimized conditions $(12 \mathrm{mg} / \mathrm{mL}$ dosage at $\mathrm{pH} 4)$ that was used in the model sample. The results in Fig. 9 reveal a high removal \% of $\mathrm{Cr}(\mathrm{VI})(94.636 \%)$ from the field samples compared with the model samples (95.77\%).

\section{Discussion}

Since the XRD analysis is used for phase identification of a crystalline material, the strongest reflection in Fig. 1 that proceeds from the 311 plane is characteristic of the crystal cubic phase. Zhao et al. obtained similar XRD planes when they have prepared $\mathrm{Fe}_{3} \mathrm{O}_{4}$ nanocomposite [36].

The FTIR analysis helps in interpreting reaction products. The decrease in the intensity of CTAB IR bands in Fig. 2b could be due to the dilution of CTAB during the functionalization process. The existence of CTAB IR bands (Fig. 2b) at 3420, 2918, 2855, and $1630 \mathrm{~cm}^{-1}$ prove the capping of $\mathrm{Fe}_{3} \mathrm{O}_{4}$ by CTAB [37]. While the disappearing of $\mathrm{N}^{+}-\mathrm{CH}_{3}$ absorption band at $1467 \mathrm{~cm}^{-1}$ (Fig. 2b) showed that the ammonium moiety of CTAB interacted with $\mathrm{Fe}_{3} \mathrm{O}_{4}$ nanoparticles.

In the TEM image (Fig. 3) there are few particles (upright corner) with a large diameter observed faceted particles. This is probably related to the high crystallinity of the particles and reflecting the cubic phase of the $\mathrm{Fe}_{3} \mathrm{O}_{4}$ crystal, which agreed with the data obtained from the XRD analysis.

In Fig. 4 the augmentation of $\mathrm{Cr}(\mathrm{VI})$ adsorption at the high adsorbent dosage could be owing to the enhanced total surface area and adsorption sites of the adsorbent at high dosages. Similar results were obtained by Mahmoodi et al. when they applied zinc ferrite nanoparticles and CTAB as an adsorbent for Direct Green (DG6) and Direct Red dyes (DR31) and (DR23) [38].

From Table 1 it is evident that the acidic medium was superior in $\mathrm{Cr}(\mathrm{VI})$ elimination than the basic medium. This may be due to in acidic medium a positively charged composite by the action of the protonated amino group $\left(\mathrm{N}^{+}\right)$of CTAB (zeta potentials of $\mathrm{Fe}_{3} \mathrm{O}_{4} /$ CTAB are positive at $\mathrm{pH}<6.4$ ) easily adsorb negative $\mathrm{HCrO}_{4}^{-}$ions through electrostatic attraction [24]. On the other side at basic $\mathrm{pH}$, the excess of $\mathrm{OH}$ ions in the alkaline solution can compete with the metal ions in binding with anion-exchange sites of the $\mathrm{Fe}_{3} \mathrm{O}_{4} /$ CTAB composite and cause a repulsion force between the adsor-

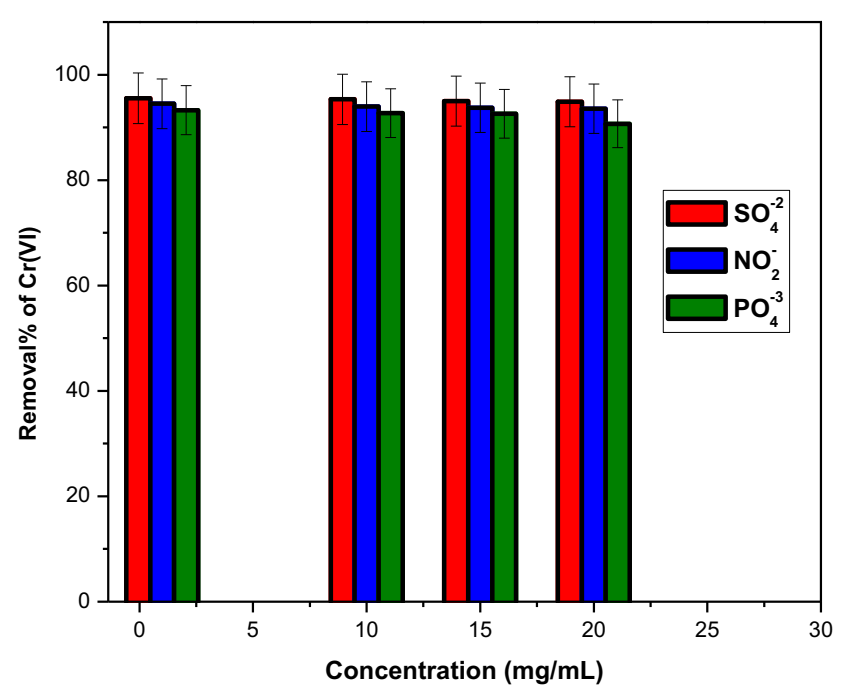

Fig. 8. The removal\% of $\mathrm{Cr}(\mathrm{VI})$ using $\mathrm{Fe}_{3} \mathrm{O}_{4} / \mathrm{CTAB}$ nanocomposite $(12 \mathrm{mg} / \mathrm{mL})$ at $\mathrm{pH}$ 4 and $12 \mathrm{~h}$ contact time in the presence of $\mathrm{SO}_{4}^{2-}, \mathrm{NO}_{2}^{-}$or $\mathrm{PO}_{4}^{3-}$ as interfering anions in a binary system.

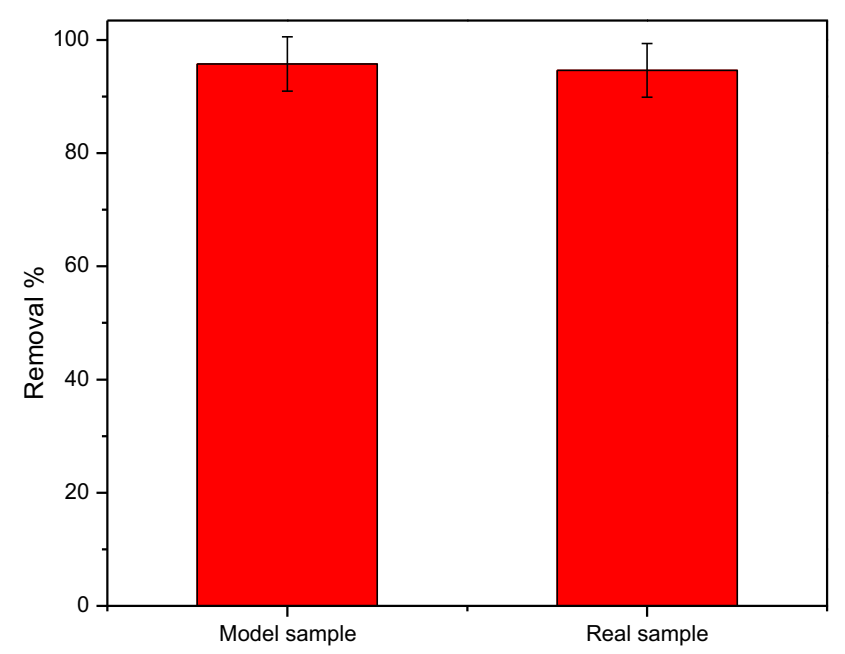

Fig. 9. Comparison between the removal\% of $\mathrm{Cr}(\mathrm{VI})$ in the model sample and real field sample using the $\mathrm{Fe}_{3} \mathrm{O}_{4} / \mathrm{CTAB}$ nanocomposite $(12 \mathrm{mg} / \mathrm{mL})$ at $\mathrm{pH} 4$.

bent surface and the $\mathrm{Cr}(\mathrm{VI})$ metal ion [8]. Moreover, it was reported that electrons can transfer from the $\mathrm{Fe}^{2+}$ (located in the core of $\mathrm{Fe}_{3} \mathrm{O}_{4}$ MNPs) to $\mathrm{Cr}(\mathrm{VI})$. This resulting in the reduction of $\mathrm{Cr}(\mathrm{VI})$ which can precipitate as insoluble $\mathrm{Cr}(\mathrm{III})$ hydroxide on the magnetite surface [39]. Free radical electrons can be formed due to the magnetic field generated by MNPs around themselves. This is visible from the removal results of composite nanoparticles in alkaline $\mathrm{pH}$ 9. The same amount of the nanoparticles $(4 \mathrm{mg} / \mathrm{mL})$ eliminates $13.5 \%$ when applying $\mathrm{Fe}_{3} \mathrm{O}_{4} / \mathrm{CTAB}$, which is less than that of the bare $\mathrm{Fe}_{3} \mathrm{O}_{4}$ nanoparticles (19.57\%).

It is supposed that there is an electrostatic attraction between CTAB on the surface and $\mathrm{Cr}(\mathrm{VI})$ ions in the solution. This can

Table 3

Langmuir and Freundlich isotherm parameters for $\mathrm{Cr}(\mathrm{VI})$ adsorption on Fe304/CTAB nanocomposite.

\begin{tabular}{|c|c|c|c|c|c|c|c|}
\hline \multicolumn{4}{|c|}{ Langmuir model } & \multicolumn{4}{|c|}{ Freundlich model } \\
\hline $\mathrm{q}_{\mathrm{m}}(\mathrm{mg} / \mathrm{g})$ & $\mathrm{b}(\mathrm{L} / \mathrm{mg})$ & $R^{2}$ & SE & $\mathrm{K}_{\mathrm{f}}$ & $\mathrm{n}$ & $R^{2}$ & SE \\
\hline 18.5 & 0.001 & 0.99 & 0.001 & 0.87 & 1.64 & 0.95 & 0.06 \\
\hline
\end{tabular}


enhance the chemical adsorption of $\mathrm{HCrO}_{4}^{-}$anions in the solution by iron cations in the core of MNPs. Chemical adsorption of $\mathrm{Cr}$ (VI) was reported before by Huang et al. when they are applying magnetic nanoparticles/multi-wall carbon nanotubes composite for adsorption of $\mathrm{Cr}(\mathrm{VI})$ in wastewater [40].

The adsorption isotherm models (Fig. 7) suggest the homogeneous metal ion adsorption activity. It may result from the similar adsorption sites of CTAB on the surface of $\mathrm{Fe}_{3} \mathrm{O}_{4}$ nanoparticles that have identical metal-binding energies.

The presence of the competitive ions such as sulfate, phosphate or nitrite at concentrations ranged from 1.0 to $20.0 \mathrm{mg} / \mathrm{L}$ does not give a significant effect on the adsorption of $\mathrm{Cr}(\mathrm{VI})$ ions. Thus, competitive adsorption of these metal ions from their binary solutions showed significant indication of high selectivity of $\mathrm{Fe}_{3} \mathrm{O}_{4} / \mathrm{CTAB}$ to $\mathrm{Cr}(\mathrm{VI})$ ion.

Applying $\mathrm{Fe}_{3} \mathrm{O}_{4} / \mathrm{CTAB}$ to wastewater field sample showed comparable $\mathrm{Cr}(\mathrm{VI})$ removal efficiency to that obtained in the model sample. Thus $\mathrm{Fe}_{3} \mathrm{O}_{4} / \mathrm{CTAB}$ can be introduced for real implementation in field application with high $\mathrm{Cr}(\mathrm{VI})$ elimination aptitude.

\section{Conclusions}

The removal of $\mathrm{Cr}(\mathrm{VI})$ from wastewater is strongly $\mathrm{pH}$ dependent. It was also influenced by the $\mathrm{Fe}_{3} \mathrm{O}_{4} / \mathrm{CTAB}$ composite or the $\mathrm{Fe}_{3} \mathrm{O}_{4}$ nanoparticles amount. Contact time after $2 \mathrm{~h}$ or the competitive anions $(20 \mathrm{mg} / \mathrm{L})$ does not have a great effect on the adsorption of $\mathrm{Cr}(\mathrm{VI})$. For $\mathrm{Cr}(\mathrm{VI})$, the maximum adsorption was achieved at $\mathrm{pH} 4$ and contact time $12 \mathrm{~h}$ using $12 \mathrm{mg} / \mathrm{mL} \mathrm{Fe}_{3} \mathrm{O}_{4} / \mathrm{CTAB}$. From this study, it can be concluded that the composite of $\mathrm{Fe}_{3} \mathrm{O}_{4} / \mathrm{CTAB}$ has high efficiency in remediation of wastewater with the advantage of low-cost and easy collection from the $\mathrm{Cr}(\mathrm{VI})$ contaminated wastewater. In future, this composite will be supported on a polymer thin film for easier reusing or recycling purposes without loss.

\section{Conflict of interest}

The authors have declared no conflict of interest.

\section{Compliance with Ethics Requirements}

This article does not contain any studies with human or animal subjects.

\section{Acknowledgement}

This work was sponsored by National Institute of Laser Enhanced Science (NILES), Faculty of Science and Centre for Environmental Hazards Mitigation (CEHM), Cairo University, Giza 12613, Egypt.

\section{References}

[1] Ayangbenro AS, Babalola 00. A New strategy for heavy metal polluted environments: a review of microbial biosorbents. Int J Environ Res Public Health 2017;14:94. http://dx.doi.org/10.3390/ijerph14010094.

[2] Kotas J, Stasicka Z. Chromium occurrence in the environment and methods of its speciation. Environ Pollut 2000;107:263-83.

[3] Zhao Y-G, Shen H-Y, Pan S-D, Hu M-Q, Xia Q-H. Preparation and characterization of amino-functionalized nano- $\mathrm{Fe}_{3} \mathrm{O}_{4}$ magnetic polymer adsorbents for removal of chromium (VI) ions. J Mater Sci 2010;45:5291-301.

[4] Khan TA, Nazir M, Ali I, Kumar A. Removal of chromium (VI) from aqueous solution using guar gum-nano zinc oxide biocomposite adsorbent. Arab J Chem 2013;10(Suppl. 2):S2388-98.

[5] Burks T, Uheida A, Saleemi M, Eita M, Toprak MS, Muhammed M. Removal of chromium (VI) using surface modified superparamagnetic iron oxide nanoparticles. Separ Sci Technol 2013;48:1243-51.

[6] Palanisamy KL, Devabharathi V, Meenakshi Sundaram N. The utility of magnetic iron oxide nanoparticles stabilized by carrier oils in removal of heavy metals from wastewater. Int J Res Appl Nat Soc Sci 2013;1:15-22.
[7] Methods for chemical analysis of water and wastes. United States Environmental Protection Agency; March 1983. http://www.state.in.us/ dnr/fishwild/files/Methods_Analysis_Water_Wastes_USEPA_March1983.pdf.

[8] Badruddoza AZMd, Shawon ZBZ, Rahman MdT, Hao KW, Hidajat K, Uddin MS. Ionically modified magnetic nanomaterials for arsenic and chromium removal from water. Chem Eng J 2013;225:607-15.

[9] World Health Organization. Guidelines for drinking-water quality, 3rd ed. Incorporating the first and second addenda, vol. 1. Recommendations, Geneva (Switzerland); 2008. Retrieved from http://www.who.int/water_sanitation_ health/dwq/fulltext. pdf.

[10] IARC. Monographs on the evolution of the carcinogenetic risk of chemical to humans, vol. 71. Suppl 4. Geneva (Switzerland): World Health Organization; 1982.

[11] Grassi M, Kaykioglu G, Belgiorno V, Lofrano G. Removal of emerging contaminants from water and wastewater by adsorption process. In: Lofrano Giusy, editor. Emerging compounds removal from wastewater (natural and solar based treatments). Netherlands: Springer; 2012. p. 15-37.

[12] Teja AS, Koh P-Y. Synthesis, properties, and applications of magnetic iron oxide nanoparticles. Progr Cryst Growth Charact Mater 2009;55:22-45.

[13] Maity D, Agrawal DC. Synthesis of iron oxide nanoparticles under oxidizing environment and their stabilization in aqueous and non-aqueous media. J Magn Mater 2007;308:46-55.

[14] Zhang L, He R, Gu HC. Oleic acid coating on the monodisperse magnetite nanoparticles. Appl Surf Sci 2006;253:2611-7.

[15] Zhou Y-T, Nie H-L, Branford-White C, He Z-Y, Zhu L-M. Removal of $\mathrm{Cu}^{2+}$ from aqueous solution by chitosan-coated magnetic nanoparticles modified with $\alpha$ ketoglutaric acid. J Colloid Interf Sci 2009;330:29-37.

[16] Yantasee W, Warner CL, Sangvanich T, Addleman RS, Carter TG, Wiacek RJ, et al. Removal of heavy metals from aqueous systems with thiol functionalized superparamagnetic nanoparticles. Environ Sci Technol 2007;41:5114-9.

[17] Vélez E, Campillo GE, Morales G, Hincapié C, Osorio J, Arnache O, et al. Mercury removal in wastewater by iron oxide nanoparticles. J Phys: Conf Ser 2016;687:012050.

[18] Kalantari K, Ahmad MB, Masoumi HRF, Shameli K, Basri M, Khandanlou R. Rapid adsorption of heavy metals by $\mathrm{Fe}_{3} \mathrm{O}_{4} / \mathrm{Talc}$ nanocomposite and optimization study using response surface methodology. Int J Mol Sci 2014;15(7):12913-27.

[19] Moradinasab S, Mahdi B. Removal of heavy metals from aqueous solution using $\mathrm{Fe}_{3} \mathrm{O}_{4}$ nanoparticles coated with Schiff base ligand. Desalination Water Treat 2016;57(9):4028-36.

[20] Schachter D. The source of toxicity in CTAB and CTAB-stabilized gold nanorods. University of New Jersey; 2013.

[21] Imae $T$, Ikeda S. Characteristics of rod like micelles of cetyltrimethylammonium chloride in aqueous $\mathrm{NaCl}$ solutions: their flexibly and the scaling laws in dilute and semi dilute regimes. Colloid Polym Sci 1987;265:1090-8.

[22] Modaressi A, Sifaoui H, Grzesiak B, Solimando R, Domanska U, Rogalski M. $\mathrm{CTAB}$ aggregation in aqueous solutions of ammonium based ionic liquids; conductimetric studies. Colloid Surf 2007;296:104-8.

[23] Anachkov SE, Danov KD, Basheva ES, Kralchevsky PA, Ananthapadmanabhan KP. Determination of the aggregation number and charge of ionic surfactant micelles from the stepwise thinning of foam films. Adv Colloid Interf 2012;183-184:55-67.

[24] Jin Y, Liu F, Tong M, Hou Y. Removal of arsenate by cetyltrimethylammonium bromide modified magnetic nanoparticles. J Hazard Mater 2012;227228:461-8.

[25] Abdul-Raheim A, Farag K, El-Saeed M, Abdel-Raouf M. Modified starch iron oxide nanocomposites as low cost absorbents for selective removal of some heavy metals from aqueous solutions. Res J Pharm Biol Chem Sci 2015;6:1197-212.

[26] Shen YF, Tang J, Nie ZH, Wang YD, Ren Y, Zuo L. Preparation and application of magnetic $\mathrm{Fe}_{3} \mathrm{O}_{4}$ nanoparticles for wastewater purification. Sep Purif Technol 2009;68:312-9.

[27] Dave PN, Chopda LV. Application of iron oxide nanomaterials for the removal of heavy metals. J Nanotechnol 2014:1-14.

[28] Bade R, Lee SH. A review of studies on micellar enhanced ultrafiltration for heavy metals removal from wastewater. J Water Sustain 2011;1:85-102.

[29] Song J, Kong H, Jang J. Adsorption of heavy metal ions from aqueous solution by poly rhodanine-encapsulated magnetic nanoparticles. J Colloid Interf 2011;359:505-11.

[30] Vijay Kumar S, Narayanaswamy R, Sripathy M, Pai KV. Comparative study of removal of chromium (VI) ion from aqueous solution using eucalyptus, neem and mango leaves. Int J Eng Res Dev 2013;8:56-61.

[31] Abdel-Ghani N, Hefny M, Chaghaby G. Removal of lead from aqueous solution using low cost abundantly available adsorbents. Int J Environ Sci Technol 2007;4(1):67-73.

[32] Azaroff LV. Elements of X-ray crystallography. New York: McGraw-Hill Book Co.; 1968.

[33] Guivar JAR, Sanches EA, Magon CJ, Fernandes EGR. Preparation and characterization of cetyltrimethylammonium bromide (CTAB)-stabilized $\mathrm{Fe}_{3} \mathrm{O}_{4}$ nanoparticles for electrochemistry detection of citric acid. J Electro Anal Chem 2015;755:158-66.

[34] Wu F-C, Tseng R-L, Juang R-S. Kinetic modeling of liquid-phase adsorption of reactive dyes and metal ions on chitosan. Water Res 2001;35(3):613-8.

[35] Bhatt SA, Sakaria LP, Vasudevan M, Pawar RR, Sudheesh N, Bajaj CH, et al. Adsorption of an anionic dye from aqueous medium by organoclays: 
equilibrium modeling, kinetic and thermodynamic exploration. RSC Adv 2012;2:8663-71.

[36] Zhao Y, Tao C, Xiao G, Wei G, Li L, Liu C, et al. Controlled synthesis and photocatalysis of sea urchin-like $\mathrm{Fe}_{3} \mathrm{O}_{4} @ \mathrm{TiO}_{2} @ \mathrm{Ag}$ nanocomposites. Nanoscale 2016;8:5313-26.

[37] Kyzas GZ, Peleka EN, Deliyanni EA. Nanocrystalline magnetite as adsorbent for surfactant removal from aqueous solutions. Materials 2013;6:184-97.
[38] Mahmoodi NM, Abdi J, Bastani D. Direct dyes removal using modified magnetic ferrite nanoparticle. J Environ Health Sci Eng 2014;12:96.

[39] Simeonidis K, Kaprara E, Samaras T, Angelakeris M, Pliatsikas N, Vourlias G, et al. Optimizing magnetic nanoparticles for drinking water technology: the case of $\mathrm{Cr}(\mathrm{VI})$. Sci Total Environ 2015;535:61-8.

[40] Huang Z-N, Wang X-L, Yang D-S. Adsorption of $\mathrm{Cr}(\mathrm{VI})$ in wastewater using magnetic multi-wall carbon nanotubes. Water Sci Eng 2015;8(3):226-32. 